\title{
1. Competitive neutrality: addressing government advantage in Australian markets
}

\section{Deborah Healey}

\section{INTRODUCTION}

The activities of government in the market have significant capacity to impede effective competition. ${ }^{1}$ Government impacts the level playing field of competition by making laws and regulations that restrict competition, by the less than comprehensive application of competition law to the entities which it owns and controls, including state-owned enterprises, and by the exemptions or exceptions it grants to itself or other favoured groups. Even where competition law expressly applies to government entities there are advantages that accrue to governmentowned or controlled bodies merely because of government ownership or control. Policy designed to address this latter issue is termed competitive neutrality policy.

The foundation of competitive neutrality policy is the principle that government business activities conducted in competition with the private sector should not have competitive advantage simply by virtue of their government ownership and control. Competitive neutrality policy implements mechanisms to ensure that advantages of this kind do not occur. This is a recognized problem worldwide and various jurisdictions have taken steps to redress the competitive balance. ${ }^{2}$ This chapter outlines the

1 See D.D. Sokol 'Anticompetitive Government Regulation', in I. Lianos and D. Sokol (eds) The Global Limits of Competition Law (Stanford University Press 2012) 83-88.

2 OECD, 'Competitive Neutrality: Maintaining a Level Playing Field between Public and Private Business: Report on OECD and National Best Practices on Competitive Neutrality' DAF/COMP (2012)7/FINAL. See also A. Capobianco and H. Christiansen, 'Competitive Neutrality and State-Owned Enterprises: Challenges and Policy Options', OECD Corporate Governance 
substantial steps taken under Australian competition law and policy to deal with the impact of government on the market and particularly with the issue of competitive neutrality. A detailed structured policy was implemented in 1995 to address competitive neutrality issues and substantial progress has been made to level the playing field for the private sector where government participates in the market. Along with corporatization and privatization of government businesses, competitive neutrality has become an accepted feature of the Australian business landscape. Complaints in this area continue to be processed and the chapter examines a representative selection of complaints and their outcomes, and looks in particular at two recent examples of the examination of complaints about competitive neutrality. This chapter also raises several outstanding issues that continue to exist despite the comprehensive nature of Australian reforms in the area.

\section{COMPETITION LAW AND POLICY REFORM IN AUSTRALIA}

Australia implemented broad-ranging reforms to its long-standing competition law and policy in 1995 following a comprehensive 1993 review that was undertaken with the agreement of the Commonwealth and the states and territories. ${ }^{3}$ The review was undertaken in response to the economic position of Australia at that time and was directed at creating a true national market in Australia within a broader competition-policy framework.

At the time of the review, competition law had developed greatly since its initial enactment in 1906 but a number of important areas of business were not subject to the existing competition law, the Trade Practices Act 1974, mainly for constitutional reasons. Australia is a federation of states and territories and the Australian Parliament's specific powers to legislate under the Constitution at that time did not allow the enactment of a truly

Working Papers No. 1, May 2011, available at http://www.oecd-ilibrary.org/ governance/competitive-neutrality-and-state-owned-enterprises_5kg9xfgjdhg6-en (accessed 31 December 2013).

3 Report by the Independent Committee of Inquiry into National Competition Policy (Canberra: AGPS 1993) (the Hilmer Report). 
comprehensive competition law. ${ }^{4}$ It was difficult, for example, for the Australian Parliament to enact a law to catch bodies such as partnerships and co-operatives, which were not deemed to be constitutional 'corporations', or to catch individuals not engaged in constitutional 'trade and commerce'. It was also difficult for a Commonwealth competition law to catch bodies owned and controlled by the states, although the 1974 Act expressly caught bodies owned and controlled by the Commonwealth. Nor was it possible for the Commonwealth to unilaterally stop states enacting laws in their own jurisdictions that overrode the competition law or exempted particular specified conduct or persons from its application, which was often done for anti-competitive or protectionist purposes. ${ }^{5}$

The outcome of the review, the Hilmer Report, emphasized that competition policy encompasses far more than just the competition law alone, and determined that Australian competition policy needed to address not only the anti-competitive conduct of firms but also areas such as unjustified regulatory restrictions on competition; the inappropriate structure of public monopolies; the denial of access to essential facilities; monopoly pricing; and competitive neutrality. ${ }^{6}$ The Hilmer Report recommended significant reforms to the $\operatorname{law}^{7}$ and the implementation of significant policy mechanisms, which were ultimately agreed to and adopted by the Australian government and the governments of each of the states. $^{8}$ The reforms expressly sought to maximize community

4 Commonwealth of Australia Constitution Act, s. 51(xx); s. 51(i). Subsequent judicial interpretation of the constitutional power with respect to corporations suggests a broader view may now be taken: New South Wales $v$ Commonwealth [2006] HCA 52.

5 For a detailed explanation of these issues see generally D. Healey, 'Australia' in M. Williams (ed.) The Political Economy of Competition Law in Asia (Edward Elgar Publishing 2013) 344.

6 See Hilmer Report (n. 3 above) 7.

7 The amendments were made in 1995 to the Trade Practices Act 1974. That Act was amended most recently in 2010 and its name was changed to the Competition and Consumer Act 2010. The most recent amendments dealt mainly with consumer law, which has also traditionally been contained in the Australian competition law.

8 See Competition Principles Agreement; Conduct Code Agreement; Agreement to Implement National Competition Policy and Related Reforms. A National Competition Council was established as part of these reforms to provide advice about competition policy matters and make various recommendations in relation to the statutory access regime contained in Part IIIA of the Trade Practices Act 1974. 
resources to improve efficiency, increase productivity and encourage innovation, to the benefit of the whole community.

The reforms that were ultimately made became known as National Competition Policy (NCP) reforms, and these included amendments to the competition law itself and the formal agreement by the states to enact and keep in place identical state laws to cover the gaps in application (that is, those areas that could not be the subject of Commonwealth law under the Constitution). They also included review by governments at Commonwealth and state level of all laws restricting competition; structural reform of public monopolies to facilitate competition; introduction of third-party access regimes to cover significant 'essential' infrastructure facilities at Commonwealth and state levels; ${ }^{9}$ some limited price oversight; and the introduction of competitive neutrality policy in all jurisdictions. ${ }^{10}$ A body called the National Competition Council (NCC) was established to support the implementation of the NCP reforms. ${ }^{11}$ Financial incentives to complete the reform process were agreed between the Commonwealth and the states based on estimated efficiency savings. Between 1998 and 2003 a total of AU\$834 million was paid by the Commonwealth to the states when they reached various milestones. These reforms fuelled substantial productivity growth. ${ }^{12}$

\section{AUSTRALIAN MARKETS AND THE ROLE OF GOVERNMENT}

The background to many of the NCP reforms, and particularly the competitive neutrality policy, was the substantial representation of government in the market and high levels of market regulation at both Commonwealth and state levels. The government in Australia has traditionally been responsible for the delivery of a wide range of services to

9 Part IIIA was introduced into the Trade Practices Act 1974.

10 The commitments to introduce competitive neutrality by each of the jurisdictions were included in the Competition Principles Agreement at clause 3, which is set out in Appendix A.

11 Following completion of the NCP agenda, some functions relating to competitive neutrality policy were referred to the Productivity Commission, where an autonomous office called the Australian Government Competitive Neutrality Complaints Office was established. See http://www.pc.gov.au/agcnco (accessed 31 December 2013).

12 Productivity Commission, Review of National Competition Policy (2005) xvii, available at: http://www.pc.gov.au/projects/inquiry/ncp/docs/finalreport (accessed 31 December 2013). 
its citizens in areas such as utilities, transport and telecommunications. It has been suggested that this dependence on government originated from the original isolation of Australian colonists from Europe and even the other Australian colonies due to the fragmented nature of the population centres almost from the outset of colonization. This situation continues today, with population still mainly centred on widely dispersed large cities in coastal areas due to the inhospitable nature of much of the landscape. This is said to have fostered and supported an attitude whereby the citizens expected central governments to provide for them. ${ }^{13}$ This feature meant, however, that reform of government businesses was particularly important to the continued productivity of the Australian economy.

When Australian economic progress faltered in the 1980s a more robust approach to the market was taken and the domestic economy was opened up to international trade. Reforms aimed at improving government efficiency were undertaken at that time. ${ }^{14}$ However, the significant impact of government businesses on the Australian economy continued, and studies emphasized the significant shortcomings of their operations, particularly their pricing practices and productivity. ${ }^{15}$ Realization of the impact of these factors led to governments pursuing a variety of reforms such as corporatization, ${ }^{16}$ commercialization, privatization and competitive tendering and contracting, even prior to NCP.

\section{COMPETITIVE NEUTRALITY POLICY AS A RESPONSE TO MARKET DISTORTION}

\subsection{Specific Factors in Distortion}

It was also well recognized that the differential treatment of government businesses may lead to serious distortions in resource allocation in the community as well as being inequitable when, for example, consumers

\footnotetext{
13 See P.D. Finn, Law and Government in Colonial Australia (OUP 1987) 2.

14 See generally D. Healey (n. 5 above) 4.

15 National Competition Council, Competitive Neutrality Reform: Issues in Implementing Clause 3 of the Competition Principles Agreement (2007) 2.

16 The Hilmer Report (n. 3 above) 300 recognized that corporatization alone would not fulfil the requirements of an appropriate model. The model required embodies five basic principles: clarity and consistency of objectives; management authority and accountability; performance monitoring; effective rewards and sanctions; and competitive neutrality.
} 
chose to purchase from a lower-priced government provider. In such cases "the production and investment decisions of that business and actual and potential competitors will be influenced. If the governmentowned business is not the least-cost producer when costs are measured on an equivalent basis, the allocation of resources towards production by this business would be inefficient'. ${ }^{17}$

Distortions identified in the Hilmer Report arose from market features such as there being no requirement for government businesses to recover costs or to price efficiently; the non-accountability of managers for their business performance; the conferral of monopoly rights on businesses, sheltering them from competitive pressures and disciplines; exemptions from paying various taxes; immunity from regulatory requirements; explicit or implicit government guarantees on debts; concessional rates of interest on loans; not being required to account for depreciation expenses; and effective immunity from bankruptcy. ${ }^{18}$ Distortions arising from this type of government conduct were said to be 'less deliberate and transparent, and typically flow from a failure to reform laws, policies and practices to keep abreast of developments as bureaucratic and monopolistic enterprises move to more commercial and competitive operating environments'. 19

The Hilmer Report also noted that there may be competitive disadvantages arising from government ownership, such as greater accountability obligations, community-service obligations, reduced managerial autonomy, requirements to comply with various government policies on wages, employment and industrial relations. Administrative review and onerous reporting requirements that do not apply to private businesses competing in the same market are examples of competitive disadvantage regularly experienced by government-owned or controlled entities.

\subsection{Competitive Neutrality Recommendations of the Hilmer Report}

Some initiatives such as some privatization and corporatization had already commenced, but the Hilmer Report for the first time recommended a comprehensive programme of reforms to address issues arising from government ownership. While it acknowledged that competition policy does not require all firms to compete on an equal footing, and that differences of size, assets, experience and culture are 'a hallmark of a

17 See Australian Government, National Competition Policy Report 20052007 (2008) 46.

18 See Hilmer Report (n. 3 above) 295-297.

19 Ibid., 295. 
competitive market economy', it did recognize that in terms of market distortions: 'by far the most systematic distortions appear to arise when government businesses participate in competitive markets. In particular, government businesses were often seen as enjoying a unique set of competitive advantages by virtue of their ownership, including exemption from tax'.20

The Hilmer Report recommended issues of competitive neutrality being dealt with in a 'systematic, nationally consistent manner' as part of NCP, recognizing that differences in approach could lead to further distortion. ${ }^{21}$ Where privatization or corporatization were not practical, competitive neutrality policy should ensure that the full economic costs of resources deployed were reflected in pricing. 'Under this approach, government businesses would be required to account for costs incurred by the business itself (such as wages), other associated costs (such as accommodation) and implicit costs (such as commercial rate of return and income tax equivalents)'. ${ }^{22}$

However, accounting measures of this kind were acknowledged to be less effective than privatization or corporatization.

\subsection{Adoption of Competitive Neutrality Policy in Australia}

As a result of the Hilmer Report, the Australian state and territory governments agreed to a set of principles supported by institutional arrangements aimed at addressing these problems in the framework of a competitive neutrality policy. A co-operative model was adopted under which all governments agreed to the principles but were individually responsible for their implementation. There was a significant degree of autonomy for individual governments in implementing the principles. The competitive neutrality principles adopted were, in summary:

- Government businesses should not enjoy any net competitive advantage by virtue of their ownership when competing with other businesses ...

- Government businesses competing against other firms within their traditional markets should be subject to measures that effectively neutralise any net competitive advantage flowing from their ownership. Unless exceptional circumstances exist, those advantages should be neutralised within one year of the introduction of competition:

\footnotetext{
20 Ibid., 293.

21 Ibid., 293.

22 Ibid., 302.
} 
(a) where the government business has traditionally provided services directly to the public, there should be a presumption that this be achieved through corporatisation; and

(b) where the government business has traditionally provided services only to other government entities, this may be achieved through corporatisation or the application of effective pricing directions ...

- Government businesses should not compete against other businesses outside their traditional markets without being subject to measures that effectively neutralise any net competitive advantage flowing from their ownership. No transition period should be permitted in this setting:

(a) where the government business has traditionally provided services directly to the public, there should be a presumption that this be achieved through corporatisation; and

(b) where the government business has traditionally provided services only to other government agencies, this may be achieved through corporatisation or the application of effective pricing directions. ${ }^{23}$

Competitive neutrality policy was formally implemented under the Intergovernmental Competition Principles Agreement, signed by each of the Commonwealth, states and territories as part of the NCP. ${ }^{24}$ Under the competitive neutrality policy, significant Government Business Enterprises (GBEs), ${ }^{25}$ classified by the Australian Bureau of Statistics as Public Trading Enterprises and Public Financial Enterprises, were subject to full Commonwealth, state and territory taxes or tax-equivalent systems, debt-guarantee fees directed towards offsetting the competitive advantages of these, and the regulations to which private-sector businesses were normally subject, such as those relating to protection of the environment, planning and approval processes, as though they were

23 Ibid., 306 et seq.

24 The Intergovernmental Competition Principles Agreement was signed on 25 February 1994. The Agreement implemented the arrangements for reform of NCP between the Commonwealth, the states and territories, and thus also provided for independent price oversight of government business enterprises which are monopoly or near monopoly suppliers of goods, structural reform of public monopolies, legislative review and the establishment of access regimes for natural monopolies; it also set up the National Competition Council. A summary of the obligations under clause 3 of the Competition Principles Agreement is set out in Appendix A.

25 A Government Business Enterprise (GBE) is a Commonwealth authority or Commonwealth company as defined by the Commonwealth Authorities and Companies Act 1997 (CAC Act) and prescribed as a GBE under the Commonwealth Authorities and Companies Regulations 1997 (CAC Act Regulations). 
private businesses. ${ }^{26}$ Other agencies undertaking significant business activities as part of a broader range of functions were to implement these processes if appropriate, or at least ensure prices charged for goods or services take those issues into account and reflect full cost attribution for the activities. ${ }^{27}$ Importantly, the competitive neutrality policy was implemented 'only to the extent that the benefits to be realized from implementation outweigh the costs'. ${ }^{28}$

As noted, governments had considerable flexibility in implementing competitive neutrality policy in their individual states and territories, but needed to document their responses and progress. ${ }^{29}$ The implementation of competitive neutrality policy was timetabled, and governments agreed to adopt individual policy statements on competitive neutrality, to set up fair and transparent individual complaints mechanisms and to report annually on progress in implementing the competitive neutrality reforms. ${ }^{30}$

\subsection{Measuring Competitive Advantage}

The Hilmer Report recognized that in some situations it would be difficult to determine the net competitive advantage or disadvantage with any precision. Where there are net competitive advantages, however,

26 Intergovernmental Competition Principles Agreement clause 3(4). Various terms have been used over time in laws and policies to describe government entities and businesses. In this chapter the use of a capitalised description for government entities describes a defined type of government entity with specific characteristics. Some of these are no longer used. The Public Performance and Accountability Act 2013 (fully operative 1 July 2014), for example, refers to 'government business enterprise' which is not capitalised, and refers to 'a Commonwealth entity of Commonwealth company that is prescribed by the rules'.

27 Ibid., clause 3(5).

28 Ibid., clause 3(6).

29 For information about the various states see e.g., New South Wales, available at: http://www.ipart.nsw.gov.au/Home/About_Us/What_We_Do/ Competitive_Neutrality; Victoria, available at: http://www.vcec.vic.gov.au/ Competitive-Neutrality; Queensland, available at: http:www.treasury.qld.gov.au/ office/knowledge/docs/ncp/ncp-competitive-neutrality.pdf; Tasmania, available at: http://www.economicregulator.tas.gov.au/domino/otter.nsf/price-v/002 (all accessed 31 December 2013).

30 Payments made to state and territory governments for compliance with their obligations under the NCP included assessment of competitive neutrality obligations: Intergovernmental National Competition Policy and Related Reforms Agreement. 
government businesses may be able to price below more efficient or equally efficient commercial rivals. It found that competitive neutrality concerns had greater impact in markets where a GBE had not traditionally operated. Different concerns arose in traditional monopoly markets. In markets opened up to competition it was not appropriate for government businesses to enjoy continuing advantages against newer and possibly more efficient competitors. In newer markets new entry by government businesses had the capacity to take away business from more efficient competitors if issues of competitive neutrality were not addressed. Competitive neutrality policy recognized that the adoption of its principles could encourage greater efficiency in resource allocation even where there is no actual or potential competition because governments are better informed about the actual cost of providing goods or services. ${ }^{31}$ Competitive neutrality policy also assists public-sector managers to more accurately assess whether the government should retain responsibility for some business activities or whether alternative means of service provision should be considered. ${ }^{32}$

\section{IDENTIFIED PUBLIC BENEFITS OF COMPETITIVE NEUTRALITY POLICY}

Identified benefits of competitive neutrality policy include:

- more efficient pricing, with resources allocated to their best uses;

- longer-term performance efficiency gains as a result of Government Business Enterprises (GBE) operating in a more competitive environment;

- savings to government from better utilization of infrastructure;

- transparency and greater efficiency in the provision of communityservice obligations; and

- increased service quality as a result of better performance monitoring. ${ }^{33}$

31 See National Competition Council, Competitive Neutrality Reform: Issues in Implementing Clause 3 of the Competition Principles Agreement (Canberra) (2007) 7 .

32 See Commonwealth Competitive Neutrality Guidelines for Managers (1998) 1 .

33 National Competition Council, Competitive Neutrality Reform: Issues in Implementing Clause 3 of the Competition Principles Agreement (1997) 2. See 
In November 2000, the Council of Australian Governments (COAG) clarified some implementation issues, agreeing that:

- Where a government business such as a university is not subject to the executive control of government it may adopt a 'best endeavours approach' to implementing competitive neutrality policy. ${ }^{34}$

- The term 'full cost attribution' in clause 3 of the Agreement would be satisfied by a range of costing methods, including fully distributed cost, marginal cost and avoidable cost.

- Governments are not required to undertake a competitive process for the delivery of community service obligations (CSOs). ${ }^{35}$

Subsequent to the completion of the NCP reforms, a new National Reform Agenda, also agreed to and implemented by the all governments through the Council of Australian Governments (COAG), continued the competitive neutrality reforms. ${ }^{36}$ The provisions of the Competition and Infrastructure Reform Agreement 2006, which implemented this continuation, are set out in Appendix B.

The preceding material discussed the principles behind the adoption of a competitive neutrality policy in Australia. The remainder of the chapter addresses more practical issues.

\section{WHAT BUSINESSES AND ACTIVITIES ARE COVERED?}

Government needs to be clear on what activities are subject to competitive neutrality policy. Bodies classified as public trading enterprises and public financial enterprises include major commodity marketing authorities, electricity authorities, railway authorities, port authorities and, at

also National Competition Council, Assessment of Government Progress in Implementing the National Competition Policy and Related Reforms (2003) para. 2.2 .

34 For an example of a university policy on competitive neutrality see the University of New South Wales Policy available at http://www.gs.unsw.edu.au/ policy/documents/commercialactivitiesguide.pdf (accessed 31 December 2013).

35 A. Trembath, 'Competitive Neutrality: Scope for Enhancement. National Competition Council Staff Discussion Paper' (2002) 8.

36 As to the National Reform Agenda generally see D. Healey (n. 5 above). 
local government level, water and sewerage businesses, governmentowned banks and government-owned insurance companies. ${ }^{37}$ As noted, clause 3(5) of the Competition Principles Agreement extends to other significant businesses that are not public trading enterprises or public financial enterprises but that undertake activities substantially funded by revenue and earn profits, or potentially earn profits. The classification of businesses as 'significant' varies from jurisdiction to jurisdiction, ${ }^{38}$ as a business activity may be operated on a commercial basis in one jurisdiction but be part of government in another jurisdiction. 'Significant' in this context is not just a measure of the size of a business but also its influence on the relevant market, and its contribution to the economy at its own level. ${ }^{39}$

The Commonwealth Competitive Neutrality Policy Statement, for example, deems all GBEs and their subsidiaries 'significant business enterprises'. A 'business' for these purposes involves the following features:

- It charges for goods and services;

- It is an actual or potential competitor either in the private or public sector - users must not be prohibited by law or policy from choosing alternative sources of supply;

- Its managers must have a degree of independence in relation to production and pricing. ${ }^{40}$

In addition, other commercial activities of non-GBE SOE agencies prescribed by regulation under the Financial Management and

37 For further comment, see Commonwealth Competitive Neutrality Policy Statement (1996), available at: http://archive.treasury.gov.au/documents/275/ PDF/cnps.pdf (accessed 31 December 2013).

38 A number of sources have compared the differences in approach between various jurisdictions. See, e.g., I. Hanrahan, 'Becoming Competitively Neutral Removing the Gilded Edge of Government Business' (2004) 12 Trade Practices L.J. 19 (Queensland and Victoria); Trembath (n. 35 above) (Commonwealth and all states and territories); and most recently, Victorian Competition and Efficiency Commission, Competitive Neutrality Interjurisdictional Comparison Paper (2013), available at: http://www.vcec.vic.gov.au/Competitive-Neutrality/Policydocumentation, under heading 'Competitive neutrality inter-jurisdictional comparison paper February 2013.pdf' (accessed 31 December 2013).

39 A full and detailed list of the types of business activities NCC thought 'should be considered for competition reform' in this context appears in National Competition Council (n. 33 above) 11.

40 National Competition Policy Report 2005-2007 (n. 17 above) 48. 
Accountability Act 1997, Commonwealth authorities or departments with a commercial turnover of at least AU\$10 million per annum, baseline costing activities for market-testing purposes and public-sector bids are considered 'significant' for the purposes of the policy.

While competitive tendering and contracting out were not mandated by the NCP, they complement competitive neutrality outcomes and, where government bids against the private sector, are subject to competitive neutrality principles. In these circumstances private bidders are more likely to consider that government does not have an unfair advantage. ${ }^{41}$

Other business activities may choose to apply a competitive neutrality policy, and may be the subject of complaint. Non-profit entities that are legally required or directed by the government to operate on a "nonprofit' basis are exempt from the requirements of competitive neutrality. ${ }^{42}$

The competitive neutrality policy also applies to local governments, with states applying policies similar to those regarding state businesses. ${ }^{43}$

\section{RELATIONSHIP WITH OTHER POLICY OBJECTIVES}

Importantly, competitive neutrality policy is not intended to override the policy obligations of government agencies or the range of social, environmental, economic and regional responsibilities of government agencies, which are all relevant to determining whether the application of competitive neutrality is in the public interest. ${ }^{44}$

Where public-interest issues are raised to justify the non-application of competitive neutrality policy, however, the government body concerned must conduct a transparent public-interest analysis to justify any decision not to apply full cost adjustments. Factors relevant to the public interest in this context have been identified as including:

- laws and policies relating to the environment;

- social welfare and equity;

41 See Trembath (n. 35 above) 39; see also Commonwealth Government Competitive Neutrality Policy Statement 1996.

42 Australian Government, Australian Government Competitive Neutrality Guidelines for Managers (2004) 2.

43 See Trembath (n. 35 above) $41 \mathrm{ff}$.

44 See, for example, Competitive Neutrality Guide to Implementation Victoria 2000, 'Foreword' (copy with author). 
- laws and policies relating to matters such as occupational health and safety, industrial relations, access and equity;

- economic and regional development, including employment and investment growth;

- the interests of consumers generally or of a class of consumers;

- the competitiveness of Australian businesses; and

- the efficient allocation of resources. ${ }^{45}$

In respect of the Commonwealth, responsibility for compliance rests with the responsible minister and in addition the GBEs and Commonwealth Companies must have their arrangements approved by the Minister for Finance.

\section{IMPLEMENTATION OF THE COMPETITIVE NEUTRALITY POLICY AT A PRACTICAL LEVEL}

\subsection{Business Pricing Decisions}

The application of the competitive neutrality policy at its most basic level requires the making of government business pricing decisions comparable with private-sector organizations by identifying all direct costs and adding competitive neutrality components where necessary. ${ }^{46}$ The first step is identifying the direct costs of a function. The second step is adjusting for relevant costs or margins that apply in the private sector and may not be fully accounted for in the direct costs to government, including things like commercial rate of return, payment of all relevant Commonwealth and state taxes, regulatory neutrality and debt neutrality. Factoring in of community-service obligations is an important consideration; however, under the competitive neutrality policy, communityservice obligations are only able to be implemented on a non-commercial basis at the explicit direction of legislation, cabinet decision or public directions from shareholder ministers. ${ }^{47}$ This process allows for consideration of the true cost to the community of these community-service

45 See Hanrahan (n. 38 above) 25, citing National Competition Council, 'Local Government and National Competition Policy' (2000) 2, available at: www.ncc.gov.au/pdf/CICOmLg-001.pdf viewed 9 February 2004 (accessed 31 December 2013).

46 See Commonwealth Competitive Neutrality Guidelines (1998) 7. See also Competition Policy Report 2005-2007 (n. 17 above) 49.

47 See Commonwealth Competitive Neutrality Guidelines (1998) 19. 
obligations. A change in November 2000 means that governments are free to determine how community-service obligations should be implemented, subject to them being 'transparent, appropriately costed and funded directly by government'. ${ }^{48}$

\subsection{Determining 'Net Competitive Advantage'}

Whether particular competitive neutrality reforms are appropriate in a particular case depends on whether the benefits of a particular reform outweigh the costs, in accordance with the Competition Principles Agreement. ${ }^{49}$ The concept of 'net competitive advantage' is thus central to competitive neutrality. Factors that are relevant to the consideration of the benefits and detriments to an individual organization include matters relating to the interests of consumers, the competitiveness of the business generally, ecologically sustainable development, social welfare and equity, industrial relations, occupational health and safety, access and equity, economic growth and regional development, and the efficient allocation of resources. ${ }^{50}$ Areas of potential net advantage identified in the NCP are: exemption from taxation liability, access to capital at concessional rates, exemption from aspects of business regulation, and pricing policies that do not take account of full production costs. ${ }^{51}$ The NCC has stated: "every factor which contributes to an ownership-related advantage or disadvantage should be identified and, to the extent practicable, the advantage or disadvantage eliminated'. ${ }^{52}$

The NCC has emphasized that the term 'net competitive advantage' does not mean that 'advantages' in one area compensate for 'disadvantages' in another, as clearly the weighing up involved in these circumstances is unlikely to lead to efficient resource-allocation outcomes and makes little sense. Rather, in each case an individual consideration of the actual facts and circumstances must occur.

\footnotetext{
48 See Trembath (n. 35 above), 50, also as to market testing.

49 Clause 1(3).

50 See National Competition Council (n. 33 above) 12.

51 Competition Principles Agreement clauses 3(4), 3(5).

52 See National Competition Council (n. 33 above) 8. The NCC also recommended using 'proxies' such as tax-equivalent regimes where advantages or disadvantages cannot be removed or transaction costs of the removal are too high.
} 


\section{COMPETITIVE NEUTRALITY COMPLAINTS}

\subsection{Complaints Procedures}

Complaints mechanisms set up under the competitive neutrality policy are the way in which interested parties pursue their concerns about government policy, conferring competitive advantages on governmentowned businesses. Complaints may allege, for example, that a business has not been exposed to competitive neutrality arrangements or is not complying with the relevant arrangements, or that the arrangements are not effective. A complaints process requires an independent arbitrator of genuine complaints, with formal advice on outcomes and reasons being given to the parties, and prompt rectification of any legitimate issues. The Commonwealth and each of the states and territories have mechanisms for the investigation of complaints through independent bodies, which report and make recommendations based on the investigations.

\subsection{Consideration of Case Examples}

Concerted implementation of structural and other mechanisms at Commonwealth, state and territory levels have led to a relatively small number of complaints about breach of competitive neutrality principles. Analysis of some of these illustrates the way in which the complaints process works and how competitive neutrality principles are viewed in various jurisdictions. The numbers of complaints investigated in the Commonwealth, the states and the territories vary widely, from one complaint in New South Wales, the most populous state with the largest economy, to 63 complaints in Victoria, the state that has the secondlargest population and the second-largest economy. ${ }^{53}$ Whether the disparities reflect more effective corporatization and implementation of the competitive neutrality policy in New South Wales, some other feature of the individual economies, different business behaviour, or some factor such as the ease of making a complaint is difficult to discern. Victoria is, however, the only jurisdiction to have more than 20 complaints.

53 Victorian Competition and Efficiency Commission, Competitive Neutrality Inter-jurisdictional Comparison Paper (2013) 9, available at http://www. vcec.vic.gov.au/Competitive-Neutrality/Policy-documentation, under heading 'Competitive neutrality inter-jurisdictional comparison paper February 2013.pdf' (accessed 31 December 2013). 
The examples below are a random selection of complaints from a number of jurisdictions. ${ }^{54}$

\subsection{Commonwealth Government Businesses}

There have been a total of 15 complaints involving the Commonwealth government. A selection of these is set out below.

\subsubsection{NBN Co}

This recent consideration of competitive neutrality policy implementation in a complex regulatory environment warrants detailed consideration, particularly because of the phase of the business at the time of the complaints. Three competitors made various complaints about the conduct of NBN Co, which was established in 2009 as a GBE wholly owned by the Commonwealth to design, build and operate a wholesale-only national broadband network (NBN) across Australia. ${ }^{55}$ The NBN was intended to connect around 93 per cent of Australian homes, schools and workplaces via fibre-to-the-premises, and to deliver broadband speeds of up to 100 megabits per second. ${ }^{56}$ Its broad purposes were to address perceived failures in the telecommunications market such as the failure of business to invest in high-speed broadband, a lack of competition in regional broadband services and a lack of uniform national wholesale pricing in the supply of broadband. Rollout of the fibre network for the NBN was expected to continue until 2020.

NBN Co had a corporate plan and an independent board and management team. The intention was that it would be funded with government equity until NBN Co had sufficient cash flows to support private-sector debt without explicit government support. ${ }^{57}$ In the longer term the government expected NBN Co to be self-funding and intended to sell down its interest within five years after the NBN was fully operational.

The government expected NBN Co to operate in a commercial manner and in accordance with a written statement of expectations, and that its approach to pricing would recognize the importance of maintaining

54 For instance, from other jurisdictions; see Victoria, available at: http:// www.vcec.vic.gov.au//Competitive-Neutrality/Invetigation-reports (accessed 31 December 2013).

55 National Broadband Companies Act 2011.

56 Australian Government Competitive Neutrality Complaints Office (2011) NBN Co, Investigation No. 14, at 3, available at: http://www.pc.gov.au/agcnco/ publications/investigation/nbnco (accessed 31 December 2013).

57 Ibid., 7. 
affordability to drive take-up rates. ${ }^{58}$ It was intended that NBN Co would provide and charge for one of the two cost components faced by retail service providers in supplying services to customers over the NBN. NBN Co would charge for access to the network (fibre, wireless or satellite) to the point of interconnection. Retail service providers would then need to transport their data from the point of interconnection to the point of presence (the backhaul). End-user prices were expected to vary because of different costs of providing the backhaul link, and where this would have the greatest impact on retail prices NBN Co was required to provide a 'transit backhaul service', such as a link to connect rural and remote areas of the network to the main competitive backhaul network. NBN Co was preparing a special-access undertaking to be approved by the Australian Competition and Consumer Commission (ACCC) under the Competition and Consumer Act 2010 to finalize pricing for its part of the NBN.

\subsubsection{The complaints Three competitors alleged that NBN Co was} not complying with the competitive neutrality policy in a number of respects, and that policy development had granted NBN Co commercial advantages. OPENetworks submitted that, while NBN Co had been announced as a provider of last resort to greenfield developments, it had actively sought business in commercially viable developments. Its pricing in those developments was allegedly contrary to competitive neutrality principles, because infrastructure and connections were being provided at no cost, an option that was unavailable to private providers. In addition, and in these circumstances, the projected rate of return of 7 per cent was impossible. The complainant also alleged that there were possible competitive neutrality breaches arising from ministerial determinations of technical specifications. Comverge Networks raised similar issues in relation to greenfield developments. It also alleged that NBN Co did not follow a fair and transparent tender process when seeking to build networks in new developments, resulting in a 'capture of intellectual property from ... competitors'. ${ }^{59}$ NBN Co's negotiations with Telstra for transfer of existing and new networks were alleged to put smaller players at a significant disadvantage. In addition, it was alleged that NBN Co's operational standards were presented as new industry standards to which all operators must adhere. The third complainant, Service Elements, characterized the greenfield development as a position in which 'NBN is

58 Ibid., 3.

59 Ibid., 2. 
able to act as a provider of "first resort" rather than a provider of "last resort" due to financial backing by the government. Its pricing of infrastructure was said to be contrary to current industry practice of charging capital costs to developers rather than to retail service providers. The complainant also alleged that its 7 per cent target rate of return did not represent a commercial rate of return as required by the competitive neutrality policy, and that NBN Co was afforded regulatory advantages as a consequence of ministerial determinations and its role in defining the footprint for the national broadband network. It made claims similar to those of the other complainants about the tender process.

9.3.1.2 The process The Australian Government Competitive Neutrality Complaints Office (AGCNCO) considered whether NBN Co was being conducted or was likely to be conducted in accordance with competitive neutrality arrangements. This involved assessing NBN Co's actual or intended compliance with the policy's requirements on taxation, debt, regulatory neutrality and commercial rate of return. ${ }^{60}$ The fact that the business activity of NBN Co was in its infancy meant that the business model had not been sufficiently implemented to yield data on what would be viewed as normal costs and revenues and in some respects required examination of whether NBN Co was in ex ante breach of the competitive neutrality policy, rather than looking at commercial results achieved up to that point. New developments across the country had access to fibre technology as it was built, and this installation was done by the private sector. The government had announced that the NBN Co would be the infrastructure provider of last resort in new developments. Developers were obliged to prepare and fund certain installations to NBN Co specifications.

9.3.1.3 Assessment of complaints AGCNCO determined that issues relating to the status of NBN Co as a provider of last resort, its long-term contracts with Telstra and the tender process to establish a panel of infrastructure providers fell outside the competitive neutrality policy. The determination on 'provider of last resort' turned on the government's own view of what those words meant. In addition, AGCNCO emphasized that the competitive neutrality policy does not mean that government businesses cannot compete with private businesses. ${ }^{61}$ Competitive advantages conferred by market position were not part of the competitive neutrality

\footnotetext{
60 Ibid., 4.

61 Ibid., 19.
} 
policy, as 'matters of business type, size, location and market position can be exploited by all businesses' ${ }^{62}$ NBN Co's use of profile to promote itself to the development industry was an operational decision and not a breach of the competitive neutrality policy. The NBN's long-term contracts with Telstra were characterized as 'a deliberate decision by the Government to establish a company of sufficient size and balance sheet strength to achieve the scale of reform required to create a structurally separated telecommunications industry in Australia'. ${ }^{63}$ The AGCNCO characterized this advantage as one of size, not one of government ownership.

Complaints about the tender process really related to NBN Co securing sensitive information submitted by tenderers. This complaint was characterized as one outside the competitive neutrality policy and in that respect NBN Co advised that tenders were conducted in accordance with government tender requirements.

\subsubsection{Pricing of infrastructure in greenfield developments The com-} petitive neutrality policy requires government businesses to set prices to earn a commercial rate of return overall. In this regard, the outcome of overall activities of a business, not the price of particular products or services, is relevant. AGCNCO noted that this approach gives the same flexibility to government businesses in setting prices as applies in the private sector, and means that a pricing model with adverse impact on competition in a particular market sector would not breach the competitive neutrality policy (although it would be subject to general competition law). In the greenfield developments example, NBN Co supplied fibre and active equipment at no cost with developer obligations being limited to meeting the cost of 'pit and pipe' construction. The cost of fibre and active equipment was recovered from retail service providers, meaning that pricing between brownfield and greenfield markets was consistent. This was a different model from that used by private providers, and would have an effect on competition in that market segment because developers would have a clear incentive to use NBN Co to reduce costs. The Department of Broadband Broadcasting and the Digital Economy (DBCDE) advised AGCNCO that the pricing model reflected the government's objective of achieving a common entry-level broadband price structure for all Australian premises across all technologies used in the rollout. AGCNCO concluded that NBN Co's pricing model for individual

\footnotetext{
62 Ibid., 20.

63 Ibid., 21.
} 
goods or services in particular market segments was not in itself a breach of the competitive neutrality policy.

\subsubsection{Expected rate of return on assets and related issues The complain-} ants alleged that the NBN Co's estimated rate of return of 7 per cent and the timeframe over which it was expected to be achieved represented a breach of the competitive neutrality policy. They claimed that: it was not achievable under the planned pricing structure; it was not a true commercial rate of return; it was not achievable within a reasonable timeframe; and it was not representative of the cost of meeting NBN Co's shareholder loans.

In response, DBCDE argued that the published 7 per cent internal rate of return was net of the estimated tax payments made after 2028, and on a pre-tax basis could be closer to 8 per cent. AGCNCO stated that the issue was whether the return from the project would deliver a commercial return commensurate with its weighted average cost of capital (WACC). At the time the complaints were considered there was no data yet available on NBN Co's financial performance to verify the achievement or otherwise of a commercial rate of return. Given the 'infancy' of NBN $\mathrm{Co}$, AGCNCO approached the issue by examining the processes used by NBN Co to determine its forecast revenue and costs, stating:

In this ex ante context, important considerations in relation to the pricing model are:

- the presence of sound processes for setting cost estimates and pricing

- the presence of appropriate sensitivity testing around the assumptions that underpin the business case

- recognition that NBN Co has adopted a 'cross-subsidy' pricing model in order to achieve the government's stated objective of offering a common entry level broadband price structure ${ }^{64}$

NBN Co had undertaken to update its corporate plan annually and an independent report considered the plan to 'be in line with a range of available domestic and international benchmarks and consistent with the stated policy objectives of government with respect to the NBN'. ${ }^{65} \mathrm{NBN}$ Co's pricing model was also subjected to sensitivity testing and would be under ACCC scrutiny to gain approval for the proposed special-access undertaking.

\footnotetext{
64 Ibid., 27.

65 Ibid., 28.
} 
AGCNCO cited the Competitive Neutrality Guidelines for Managers, which provide guidance on how to determine a commercial rate of return when, as in this case, a benchmark has not been set by the government. Relying on the Guidelines, AGCNCO looked at risk broadbanding rather than the WACC because a comparable WACC was not easily determined and managers were only able to approximate the market risk of the business. Using risk broadbanding, analysis showed that the expected after-tax internal rate of return of 7 per cent would not deliver a commercial rate of return. ${ }^{66} \mathrm{DBCDE}$ and NBN Co argued that NBN Co's commercial rate of return should be viewed in the context that NBN Co had been established to deliver both commercial and social benefits. NBN Co was not, however, transparently funded for delivery of noncommercial benefits that the government required and AGCNCO had not been provided with quantification of the non-commercial benefits expected. In these circumstances AGCNCO was unable to determine whether the difference between a commercial rate of return and the 7 per cent projected was adequately explained by the non-funded community service obligations. AGCNCO concluded that there was a potential ex ante breach of the competitive neutrality policy. It recommended that the government arrange for an analysis of the non-commercial benefits required and put in place accountable and transparent community service obligations funding. It also recommended that NBN Co adjust its pricing model by taking into account funding by the government for its community service obligations, and show how the adjusted pricing model would achieve a commercial rate of return that reflected its risk profile.

The complainants also argued that the 30-year model with positive cash flows from 2022 was unreasonable from a commercial perspective and represented a breach of the competitive neutrality policy. AGCNCO noted that the competitive neutrality policy and guidelines provided limited guidance on what was a reasonable timeframe to earn a commercial rate of return. The reasonableness of the length of the start-up phase was the real issue here. AGCNCO concluded that in the absence of a quantification of NBN Co's CSOs the expected timeframe for achieving a commercial rate of return (12 years) represented a potential ex ante breach of the competitive neutrality policy.

Another argument of the complainants was that the government's commitment of funds to NBN Co represented a shareholder loan and should be viewed as a debt when looking at competitive neutrality compliance. The competitive neutrality policy, however, only requires

66 Ibid., 32. 
debt neutrality provisions to be applied when monies are borrowed from the government or raised in the market. AGCNCO concluded that the equity funding of NBN Co was not subject to the debt-neutrality provisions of the competitive neutrality policy.

As to the complaint about ministerial determinations, AGCNCO found that as no ministerial determinations had been made, there had been no breach of the competitive neutrality policy in that respect. In any event, if determinations did not exempt NBN Co from regulations that applied to other competitors, there would not be a breach of the regulatory neutrality requirements of the competitive neutrality policy. ${ }^{67}$

\subsubsection{Complaint re AIS Swim School}

The AIS Swim School was a commercial activity of the Australian Sports Commission (ASC), the body responsible for sports development at elite and grass-roots levels. The ASC conducted learn-to-swim classes, recreational swimming, aqua-aerobics and other aquatic activities at the Australian Institute of Sport (AIS) facilities. A competitor swim school lodged a complaint with the Minister for Sport and Tourism and the AIS. The complaint alleged that the AIS Swim School was subsidized by the ASC, its government owner, and that its costing and pricing policy did not comply with the competitive neutrality policy. The complaint also stated that it was inappropriate for the AIS Swim School to replicate services already available in the area in the private sector, and that if it was to continue in this way it should adopt a corporatized model.

Legislation setting up the AIS required it to allow individuals and community groups to have access to AIS facilities, and expressly provided for provision of commercial services at AIS facilities.

The CCNCO (Commonwealth Competitive Neutrality Complaints Office, predecessor of AGCNCO) agreed that AIS Swim School was a business activity under the Commonwealth Competitive Neutrality Policy Statement. It found, however, that it was inappropriate for AIS Swim School to be subject to competitive neutrality arrangements because it had no significant net competitive advantage resulting from government ownership. For the purposes of this consideration, the costs of providing AIS Swim School services were the avoidable costs of providing the services, given that the pool facilities were constructed and operated primarily to meet the core purpose of the Australian Sports Commission - the servicing of the development of elite athletes. The same principle would be applied to other swim schools using facilities predominantly

67 Ibid., 37. 
associated with other users such as schools or health clubs. The incremental costs associated were embodied in a facilities rent charge to the AIS Swim School, so that in effect the AIS Swim School's costs were not being subsidized by the AIS.

In any event, CCNCO found that the AIS Swim School was not advantaged by not applying competitive neutrality principles. There was no significant competitive advantage from its tax-exempt status because of its size and the nature of its operations. It had no significant advantage as a result of government ownership. It costed and priced its activities consistently with normal commercial behaviour. $\mathrm{CCNCO}$ did recommend, however, that the AISSS be subject to appropriate competitive neutrality arrangements, as this would involve negligible cost. ${ }^{68}$

\subsubsection{ABC production facilities}

The Australian Broadcasting Corporation (ABC), the national Australian broadcaster, owned production facilities and equipment and employed staff to produce television programmes for broadcast on its network. The ABC Production Portfolio (ABC Productions) also tendered on a commercial basis to provide production facilities and labour to other film and television producers. A competitor complained that $\mathrm{ABC}$ and $\mathrm{ABC}$ Productions were not complying with competitive neutrality principles, on the basis that ABC Productions had access to resources purchased for non-commercial production that enabled it to provide services at a lower cost than its competitors. The Commonwealth Competitive Neutrality Statement identified the sale of consumer goods and studio rentals as business activities subject to competitive neutrality despite the fact that the turnover for the studio-rentals business fell below the threshold for automatic application. CCNCO emphasized that it was not usually necessary to examine the internal costing or pricing policies of a stand-alone GBE to determine whether it was complying with the competitive neutrality principles because the assessment could be based on its aggregate performance. However, where a business unit draws heavily on assets and resources of a non-commercial parent agency the level of costs allocated to the unit could determine its profitability. In this situation both the level of profits and the construction of the cost base were examinable, but investigation of individual transactions was not required. Here the key question was whether the prices set generated

68 Commonwealth Competitive Neutrality Complaints Office (1999) Australian Institute of Sport Swim School, Investigation No. 2, available at: http://www. pc.gov.au/_data/assets/pdf_file/0010/5401/report2.pdf (accessed 31 December 2013). 
sufficient revenue to cover all relevant costs. This required assessment of whether there was an appropriate methodology for allocating costs to the commercial activity; whether there were appropriate accounting and internal control systems to demonstrate that the costing methodology was followed in practice; and whether the revenue was sufficient to cover all relevant costs, including taxes, that a private business would pay. CCNCO found that the method of costing labour and facilities used by ABC Productions exceeded the minimum cost benchmark consistent with competitive neutrality principles. The accounting and control system provided a basis for ensuring that all relevant costs were identified and its costing and pricing approach was followed in practice. Even allowing for the impact of taxation, ABC Productions generated a commercial level of profits in 1998-1999. The allocation of costs to ABC Productions was found to be consistent with competitive neutrality principles and no action was required. ${ }^{69}$

\subsubsection{Meteorological services to aviation}

A subsidiary of a New Zealand government meteorological body (Metra) lodged a complaint alleging that the Civil Aviation Safety Authority's administration of aviation regulations conferred a regulatory advantage on the Bureau of Meteorology (Bureau) by preventing Metra from competing in the market for the supply of meteorological services to the aviation industry. The Bureau was a statutory authority funded by the Commonwealth budget to provide weather forecasting and other meteorological services within Australia, and it also provided services to the aviation industry on a cost-recovery basis. The aviation services were regulated by the Civil Aviation Safety Authority (CASA). The Bureau resisted the introduction of full competition arguing that a fully competitive commercially viable aviation weather service does not exist anywhere in the world. Submissions indicated that the Airports Association of Australia was happy with the current arrangement, although other interested parties favoured a more competitive model.

$\mathrm{CCNCO}$ found that a component of the Bureau's services constituted a business activity for the purposes of the competitive neutrality policy. Various interested parties had different views on whether the market was contestable or not contestable. CCNCO looked at whether there could be competition for the market or in the market and concluded that some of

69 Commonwealth Competitive Neutrality Complaints Office (2000) ABC Production Facilities, Investigation No. 4, available at: http://www.pc.gov.au/ data/assets/pdf_file/0012/5403/report4.pdf (accessed 31 December 2013). 
the suggestions lay outside competition policy. The complainant thought that three models of competition could exist:

- a basic value-adding service which could entail Metra adding further detail and precision to the existing service for specific critical destinations and route-forecast elements;

- an expanded value-added service whereby Metra would become the sole supplier for its own customers. Data collection and basic collation would continue to be undertaken by the Bureau, funded under cost-recovery arrangements;

- a competitive tendering model whereby the government would make particular products contestable.

CCNCO noted that the Bureau and the Minister for Environment and Heritage had cited several reasons why the market should be reserved for the Bureau, including the nature of the good supplied, safety considerations and Australia's international aviation obligations. The CCNCO determined that there was not a case for preventing competition for value-added services on safety grounds. Australia's obligations under the Chicago Convention did not act to limit competition in the provision of meteorological services that were beyond the requirements of international conventions.

Ultimately the $\mathrm{CCNCO}$ did not consider that there was a case for restricting competition in the provision of value-added meteorological services to the aviation industry. The costs would be low and the overall impact on efficiency was likely to be positive. The Parliamentary Secretary to the Minister for the Environment and Heritage indicated to the CCNCO that other models of competition were under active investigation. The $\mathrm{CCNCO}$ recommended that the government should complete its consideration of the options for introducing competition in the provision of these services as soon as possible, and if no other model was likely to deliver greater net benefits to the community than competitive provision of value-added services, that approach should be implemented forthwith. ${ }^{70}$

\subsubsection{Defence Housing Australia}

AGCNCO received a complaint from the Real Estate Institute of Australia (REIA) regarding Defence Housing Australia (DHA)'s exemptions

70 Commonwealth Competitive Neutrality Complaints Office (2001) Meteorological Services to Aviation, Investigation No. 7, AusInfo, Canberra. 
from licensing requirements for the provision of property sales and management services. REIA alleged that DHA, a statutory body with responsibility for providing housing for members of the defence forces and other government agencies, acted as an estate agent and that its exemptions were anti-competitive because they provided a more favourable business environment for DHA than for private-sector real-estate agents. DHA did not need to comply with requirements such as those on continuing professional development for agents, maintaining a registered office and complying with prudential requirements such as trust accounts for bonds paid by tenants and insurances.

DHA was identified in the government's Competitive Neutrality Policy Statement as a government business activity subject to the competitive neutrality policy. AGCNCO considered whether DHA could be viewed as operating a real-estate business and should be subject to the same regulatory requirements applying to real-estate agents. Legislation regulating real-estate agents was introduced to safeguard individuals in their dealings with agents, to establish a process whereby only 'suitable' persons with appropriate qualifications could act as agents and to protect consumer transactions. AGCNCO noted that agents act on behalf of others for reward in transactions. The key issue was whether DHA operated as a real-estate agent in its transactions, and to determine this issue AGCNCO considered whether DHA would be required to comply with the relevant laws if it was trading as a private business in each state or territory. It concluded that while its activities were of a similar nature they were performed on its own behalf and not on behalf of a third party. DHA itself characterized its activities as similar to a private-sector property developer rather than an agent. In the circumstances DHA did not gain a regulatory advantage as a result of being government owned and had not breached the regulatory neutrality provisions. ${ }^{71}$

\subsection{New South Wales}

\subsubsection{State Valuation Office}

In State Valuation Office, the only case from New South Wales, three private valuation firms complained that the State Valuation Office (SVO) had failed to comply with the competitive neutrality policy in tendering for specific contracts to provide land-valuation services for the NSW

71 Australian Government Competitive Neutrality Complaints Office (2008) Defence Housing Australia, Investigation No. 13, available at: http:// www.pc.gov.au/_data/assets/pdf_file/0004/79330/report13-defencehousing.pdf (accessed 31 December 2013). 
Valuer General and a Victorian Council. At the time of the complaints the SVO operated as a commercial business unit in the NSW Department of Commerce and it competed with private-sector firms to provide landvaluation services to the NSW Valuer General and private clients. The work was awarded each year following tenders for NSW Local Government areas and the contracts were generally for three or four years. ${ }^{72}$

In a detailed consideration the Independent Pricing and Review Tribunal (IPART) found that the pricing methodology employed by SVO was consistent with the NSW competitive neutrality policy. In applying the methodology, however, SVO in two cases underestimated the resources it would require to fulfil the contracts. IPART made no finding on whether this was done in breach of competitive neutrality principles or was done in error. Some adjustments were required to the costing of insurance premiums, which appears to be lower than that of private-sector valuers. SVO's profit calculations were distorted by the exclusion of some corporate overheads. For the future, IPART recommended that SVO should improve its documentation to assist with further compliance reviews. ${ }^{73}$

\subsection{Queensland}

\subsubsection{Cattletrain}

In the Cattletrain complaint against Queensland Rail's livestock transport service, Cattletrain alleged that Queensland Rail breached competitive neutrality principles in Central Queensland because it priced its services lower than a private operator could by offering more favourable prices to selected customers to attract business, discounting livestock freight rates to particular businesses and employing procedures and operational advantages relating to animal-welfare transport standards. It was alleged that Queensland Rail influenced the development of these standards in a way that gave Queensland Rail an advantage over private-sector competitors.

The Queensland Competition Authority (QCA) found that Queensland Rail did enjoy a competitive advantage and priced these services below a

72 In investigating these complaints, IPART referred to the NSW Treasury documents Policy Statement on the Application of Competitive Neutrality, January 2002, and Guidelines for Pricing of User Charges, June 2001.

73 Independent Pricing and Review Tribunal (2004) Investigation of Competitive Neutrality Complaints against State Valuation Office, available at: http:// www.ipart.nsw.gov.au/files/637ea1f8-f819-42a5-b485-9f670093fae2/Investigation _of_Competitive_Neutrality_Complaints_against_the_State_Valuation_Office_-_ 8_October_2004.pdf (accessed 31 December 2013). 
level that a private organization could attain. Slightly more favourable prices were provided to certain clients in the form of volume discounting without supporting financial information, and this could only have been done by an entity that did not cover its costs, that is, that was government-owned or controlled. Other discounts to customers in exchange for operational efficiencies did not result from government ownership or control, and were in fact also applied by some commercial operators. The substitution of larger wagons for smaller wagons at the same price was due to operational requirements rather than as a result of government ownership. The complaint in relation to animal-welfare issues was not substantiated, as no advantage arose from government ownership.

Open-ended financial arrangements between Queensland Rail and the Queensland government that had applied at the time of the complaints had ceased so no further action was necessary. ${ }^{74}$

\subsection{Victoria}

\subsubsection{City of Ballarat childcare centres}

In a case from Victoria, the City of Ballarat ran two childcare centres. A competitor complained to the Victorian Competitive Neutrality Unit (CNU) that the Council childcare centres operated at a considerable loss and were subsidized by the City Council. A further complaint was made that the Council was paying their childcare workers wages above the level prescribed by the Federal Award which applied to all childcare centres.

The childcare services were found to be business activities, as they were provided for a fee. They were 'significant' because of their size relative to the size of businesses in the relevant market, comprising approximately 13 per cent of the market, in which there were a reasonable number of competitors of a moderate size. Under the Victorian competitive neutrality policy ${ }^{75}$ government agencies falling within this definition were required to determine costing and pricing for their business activities. Where competitive neutrality measures were at risk of jeopardizing other public policy objectives, options for achieving all policy objectives, including competitive neutrality pricing, were explored

74 Queensland Competition Authority (2001) Complaint by a Road Transport Operator against Queensland Rail, Final Report; available at: http://ncp.ncc. gov.au/docs/Queensland's\%20sixth\%20annual\%20report\%20on\%20implementing \%20the\%20NCP,\%20March\%202002.pdf (accessed 31 December 2013).

75 Victoria, Competitive Neutrality Policy 2000 (copy with author). 
through a documented public-interest process. ${ }^{76}$ The Council undertook a public-interest test process looking at the issue of community need and weighing it against competitive neutrality obligations against the background of an identified shortfall of childcare services in the relevant area. The Council had determined that the imposition of full-cost pricing of services would affect the ability of the community to access the services. As a result, the Council was required to subsidize services to meet community needs. No commercial rate of return could thus be achieved. $\mathrm{CNU}$ found that the Council had undertaken a thorough review of its public-policy objectives and had justified its childcare programme subsidy. CNU determined that the Council had not breached Victoria's competitive neutrality policy. The CNU noted that the Council had not become involved in developing new childcare centres to cater for identified need but had commenced an assessment of needs that it intended to provide to commercial stakeholders in the area. ${ }^{77}$ This example is useful because the competitive neutrality policy breach was justified in all of the circumstances by a detailed consideration of the public-interest test.

\section{MEASUREMENT OF PROGRESS IN COMPETITIVE NEUTRALITY REFORM}

An early analysis of competitive neutrality implementation indicated concern because some governments identified significant business enterprises by size alone, which would have exempted many government business activities having a significant market influence arbitrarily from reform. ${ }^{78}$ The NCC indicated that specific business activities should be identified that would be subject to competitive neutrality principles. The NCC was also concerned because the mechanisms for complaints handling established by some governments lacked transparency. Adoption of a competitive neutrality framework was particularly important in relation

76 Competitive Neutrality Unit, Department of Treasury and Finance (2003) Competitive Neutrality Complaint Investigation Re City of Ballarat 1 (copy with author).

77 Ibid.

78 National Competition Council, Annual Report 1995-1996, 14, available at: http://ncc.gov.au/publications/C41 (accessed 31 December 2013). 
to competitive tenders where an in-house provider participated in the tender process. ${ }^{79}$

An assessment of the progress of governments by the NCC in 2003 indicated that most jurisdictions had committed to full-cost attribution for their significant business activities but that they had struggled to deal with some issues, including the application of marginal pricing or competitive pricing strategies in the short term. Coverage of the governments' competitive neutrality policies was generally satisfactory, although it could be improved. ${ }^{80}$ Slow policy implementation allowed in some industries detracted from the results. Complaints handling could be improved in some respects. ${ }^{81}$

In its 2005-2006 Annual Report, the last before the formal finalization of National Competition Policy, the NCC stated that progress in relation to competitive neutrality had been mixed. All states and territories had corporatized major government businesses, and other significant businesses had been exposed to competitive neutrality principles. Competitive neutrality complaints units had been established. There was, however, scope for improving coverage of competitive neutrality principles and the operation of complaints mechanisms. ${ }^{82}$ Both the NCC and the Productivity Commission ${ }^{83}$ stated that commitment to better governance was required to ensure NCP reform objectives. The Productivity Commission stated: 'failure to meet this objective has potentially serious consequences given that government-owned enterprises have combined assets of more than $\mathrm{A} \$ 174$ billion and generate $\mathrm{A} \$ 55$ billion in revenue annually' ${ }^{84}$

The Productivity Commission noted in particular that the majority of government-owned enterprises monitored failed to obtain commercial

79 The NCC noted that it would place particular weight, in assessing the compliance of a jurisdiction with implementing the competitive neutrality policy, on allegations of non-compliance and how they were dealt with. Ibid., 15.

80 National Competition Council (n. 33 above) 28. New South Wales' coverage was potentially broadest as it had assumed that competitive neutrality principles would apply unless an individual government business presented a case that costs exceeded benefits. West Australia had not required businesses operated by public hospitals to apply competitive neutrality principles.

81 Ibid., at 2.13.

82 National Competition Council, Annual Report 2005-2006, 59, available at: http://ncc.gov.au/publications/C41 (accessed 31 December 2013).

83 Productivity Commission (2005) (n. 12 above).

84 Ibid. 
rates of return. ${ }^{85}$ In 2004-2005, aggregate profitability increased in areas such as electricity, water and urban transport, but declined in railways, forestry and ports. ${ }^{86}$

The numbers of actual complaints about competitive neutrality policy issues are small when compared to the substantial areas of business conducted by government bodies. This may be because there are necessarily many variants in the implementation of individual competitive neutrality policies. Alternatively, it may be that not many businesses consider themselves to be disadvantaged when competing with government businesses or recognize that they are so disadvantaged.

Significant steps have been taken in implementing a competitive neutrality policy in Australia by the Australian government and the states and territories. This chapter has attempted to provide a snapshot of the reasons for implementation of the Australian competitive neutrality policy, how it was implemented and some of the issues arising. Continued diligence should provide additional economic rewards in the more efficient delivery of competitive government services to the benefit of the community as a whole.

\section{REMAINING QUESTIONS}

The success of the NCP reforms in Australia was underpinned by recognition by all governments of the urgency of comprehensive reform, broad agreement on priority areas, a solid conceptual framework, and highly effective procedural and institutional mechanisms. ${ }^{87}$ The conclusions of the Productivity Commission on the issue of profitability indicate that despite elaborate systems for addressing the issue of competitive neutrality, levelling the playing field by insisting on a commercial rate of return for all government businesses is still a long way off. This suggests that even with the advantages provided by government ownership or control, these bodies struggle to achieve profitability. Of course on that score they are not alone: many private businesses are not profitable. The ex ante nature of the consideration in the NBN Co case cast no light on that issue. The general failure to

85 As to the measurement of rates of return in a competitive neutrality context, see generally Commonwealth Competitive Neutrality Complaints Office Research Paper 'Rate of Return Issues' (1998), available at: http://www. pc.gov.au/agcnco/publications/research/cnror (accessed 31 December 2013).

86 Productivity Commission (n. 12 above).

87 Ibid., xxiii. 
achieve profitability raises the issue of whether the profitability of government businesses should be considered and measured in identical fashion to private businesses. This issue may need to be addressed in the context of the on-going policy development in the area.

Issues of competition law and policy are a complex mix. Circumstances are never precisely the same in individual examples, for reasons that include the political economy of particular jurisdictions and the aims and coverage of particular competition laws in a jurisdiction. Australian competition law, for example, takes a substantial economic approach but allows for public-benefit consideration in a number of respects, particularly in areas of market failure. The Australian methodology for tackling the role of the government in the market is comprehensive and is considered to be a successful approach to dealing with the issue of competitive neutrality.

The Australian approach will not be appropriate for all jurisdictions. Just as competition laws vary between jurisdictions, so will approaches to achieving competitive neutrality. In many developing jurisdictions the realization that competitive neutrality is an issue and that implementation of some form of competitive neutrality policy should be considered is a truly significant step towards levelling the playing field between private and government businesses. Australia does, however, provide one example of a country that has adopted a competitive neutrality policy with considerable success. ${ }^{88}$

Despite the comprehensive competition policy initiatives of the last 20 years, further change is foreshadowed. A new Australian government elected in September 2013 has instituted an 'independent "root and branch" review' of Australia's competition law and policy 'in recognition of the fact that the Australian economy has changed markedly since ...

88 At the time of publication Australia had embarked on a further comprehensive review of competition law and policy: http://www.competition policyreview.gov.au/terms-of-reference, March 2014. A key area of consideration is government involvement in markets. The draft report of September 2014, available at http://www.competitionpolicyreview.gov.au/draft-report, contains overwhelming support for the concept of competitive neutrality. It calls for governments to re-commit to competitive neutrality; review and updating of policies; and greater transparency of compliance and the findings of investigations by further public reporting - see Recommendations p. 36, and full details in Ch. 11. The final report is expected in March 2015. 
1993'. ${ }^{89}$ The review is the most comprehensive since the Hilmer Review. ${ }^{90}$ It is very wide ranging, and is based on the following policy objectives:

1.1. no participant in the market should be able to engage in anti-competitive conduct against the public interest within that market and its broader value chain;

1.2. productivity boosting microeconomic reform should be identified, centred on the realisation of fair, transparent and open competition that drives productivity, stronger real wage growth and higher standards of living;

1.3. government should not be a substitute for the private sector where markets are, or can, function effectively or where contestability can be realised; and

1.4. the need to be mindful of removing wherever possible, the regulatory burden on business when assessing the costs and benefits of competition regulation. ${ }^{91}$

Among its 'key areas of focus', the review will look at 'government involvement in markets through GBEs, direct ownership of assets and competitive neutrality policy, with a view to reducing government involvement where there is no longer a clear public interest need'.

This suggests that there is an appetite for further privatisation of government businesses which would once again reduce the impact of government on competition in the market, reducing the need for competitive neutrality policy initiatives.

Despite its comprehensive nature the review is to report within 12 months. The approach to issues of competitive neutrality and, hence, the outcome of this review are still unknown. It may recommend a lesser involvement by Government in contestable markets; however, while there is any government involvement at all in contestable markets, competitive neutrality policy, in one form or another, will continue to be an important tool for ensuring a level playing field between government business and private market participants.

89 See Competition Policy Review Terms of Reference: available at: http:// competitionpolicyreview.gov.au/terms-of-reference/ (accessed 31 March 2014). These Terms of Reference were released in March 2014.

90 The Dawson Review, which reported in 2003, was more concerned with amendment of the competition law itself, rather than competition policy. See http://tpareview.treasury.gov.au/content/termsofref.asp for the Dawson Terms of Reference and http://tpareview.treasury.gov.au/content/report.asp for the Report (accessed 31 March 2014).

91 See Competition Policy Review Terms of Reference (n. 89 above). 


\section{APPENDIX A: CLAUSE 3 OF THE COMPETITION PRINCIPLES AGREEMENT 92}

(1) The objective of competitive neutrality policy is the elimination of resource allocation distortions arising out of the public ownership of entities engaged in significant business activities: Government businesses should not enjoy any net competitive advantage simply as a result of their public sector ownership. These principles only apply to the business activities of publicly owned entities, not to the non-business, non-profit activities of these entities.

(2) Each Party is free to determine its own agenda for the implementation of competitive neutrality principles.

(3) A Party may seek assistance with the implementation of competitive neutrality principles from the Council. The Council may provide such assistance in accordance with the Council's work program.

(4) Subject to subclause (6), for significant Government business enterprises which are classified as 'Public Trading Enterprises' and 'Public Financial Enterprises' under the Government Financial Statistics Classification:

(a) the Parties will, where appropriate, adopt a corporatisation model for these Government business enterprises (noting that a possible approach to corporatisation is the model developed by the intergovernmental committee responsible for GTE National Performance Monitoring); and

(b) the Parties will impose on the Government business enterprise:

(i) full Commonwealth, State and Territory taxes or tax equivalent systems;

92 These principles were refined by further agreement of the Council of Australian Governments (COAG), which agreed at its November 2000 meeting that:

- the NCC's assessment of governments' application of the competitive neutrality policy to government businesses over which they had no executive control (such as universities) should be based on a 'best endeavours' approach;

- the term 'full cost attribution' could cover a range of methods, including fully distributed cost, marginal cost and avoidable cost;

- governments were not required to establish a competitive process for their delivery of CSOs; and

- governments are free to determine who should receive a CSO payment or subsidy, but such payments should be transparent, appropriately costed and budget funded.

As noted in National Competition Council, Assessment of Governments Progress in Implementing the National Competition Policy and Related Reforms (2003) Volume 1, at 2.1. 
(ii) debt guarantee fees directed towards offsetting the competitive advantages provided by government guarantees; and

(iii) those regulations to which private sector businesses are normally subject, such as those relating to the protection of the environment, and planning and approval processes, on an equivalent basis to private sector competitors.

(5) Subject to subclause (6), where an agency (other than an agency covered by subclause (4)) undertakes significant business activities as part of a broader range of functions, the Parties will, in respect of the business activities:

(a) where appropriate, implement the principles outlined in subclause (4); or

(b) ensure that the prices charged for the goods and services will take into account, where appropriate, of the items listed in paragraph 4(b) and reflect full cost attribution for these activities.

(6) Subclauses (4) and (5) only require the Parties to implement the principles specified in those subclauses to the extent that the benefits to be realised from implementation outweigh the costs.

(7) Subparagraph (4)(b)(iii) shall not be interpreted to require the removal of regulation which applies to a Government business enterprise or agency (but which does not apply to the private sector) where the Party responsible for the regulation considers the regulation to be appropriate.

(8) Each party will publish a policy statement on competitive neutrality by June 1996. The policy statement will include an implementation timetable and a complaints mechanism.

(9) Where a State or Territory becomes a Party at a date later than December 1995, the Party will publish its policy statement within six months of becoming a Party.

(10) Each Party will publish an annual report on the implementation of the principles set out in subclauses (1), (4) and (5), including allegations of non-compliance.

\section{APPENDIX B: COMPETITION AND INFRASTRUCTURE REFORM AGREEMENT OF 10 FEBRUARY 2006 - CHAPTER ON COMPETITIVE NEUTRALITY OF GOVERNMENT BUSINESS ENTERPRISES}

6.1 The Parties agree to enhance the application of competitive neutrality principles to government business enterprises engaged in significant business activities in competition with the private sector:

\section{Objectives}

a. That the enterprise has clear commercial objectives. 
b. That any non commercial objectives or obligations established for the enterprise are clearly specified and publicly reported.

c. That enterprises do not exercise regulatory or planning approval functions in circumstances in which they compete with private sector enterprises.

\section{Governance}

d. That the responsibilities of the governing board of the enterprise and the performance measures against which the board will be held accountable are published.

e. That the governing board is appointed on the basis of particular skills needed by the board.

f. That having received strategic guidance from the government about the achievement of its objectives, the enterprise has operational autonomy in the day to day management of its affairs.

g. That the dividend policy applicable to the enterprise should be clearly and publicly specified.

h. That any payments to the government as shareholder or for the purposes of competitive neutrality, such as taxes, tax equivalent payments, special dividends, capital repayments, are identified in a transparent manner.

\section{Reporting}

i. That at least annually the enterprise will report publicly on its commercial performance and on its performance of any non commercial activities.

j. That any directions given to the enterprise by the government are published.

k. That where the legislation establishing an enterprise derogates from competitive neutrality the derogation has been published. 